\title{
Do Blood Groups Link with Feet Size?
}

\author{
Muhammad IQ and Nabiha $\mathrm{Z}^{*}$ \\ Institute of Molecular Biology and Biotechnology, Bahauddin Zakariya University, \\ Pakistan
}

*Corresponding author: Nabiha Zulfiqar, Institute of Molecular Biology and

\section{Research Article}

Volume 3 Issue 1

Received Date: December 11, 2018

Published Date: January 08, 2019

DOI: $10.23880 /$ mjccs-16000194

Biotechnology, Bahauddin Zakariya University, Multan, Pakistan, Email: nabihakhan120@gmail.com

\section{Abstract}

Object of the present study was to correlate blood grouping with the feet size. 176 students were participating in this project. $\mathrm{ABO}$ blood group system consists of $\mathrm{ABO}$ gene. The gene is located on log arm of ninth chromosome.

Keywords: Foot Size; Blood Grouping

\section{Introduction}

ABO blood group system was discovered by Karl Landsteiner in 1909. ABO blood group system is classified according to the presence of one or both or neither of $A, B$ or $O$ antigen $\mathrm{ABO}$ blood group system is consist of $\mathrm{ABO}$ gene. This gene is located on log arm of ninth chromosome. It is one of the most important blood group systems out of 36 blood group system. It is present in animals [1].

RH blood group was discovered by Karl Landsteiner in 1937. The Rh blood group system is classified according to the presence of $\mathrm{Rh}$ factor. The $\mathrm{Rh}$ is abbreviation of the monkey at the time it was believed that the antigen found in both human and the monkey. But later it was proved that Rh not found in human [2].

The size of your feet is also change when you drop your pounds. Feet flatten over time due to the loss of elasticity in supporting tendons and ligaments resulting in a lower arch and an elongation of the sole along with a spreading of the toes. Foot size also changes by wearing tight shoes. The shoe make feet thinner.

\section{Material and Methods}

Tooth pick, glass slides, Anti serum, Needle I took three antibodies A, B, D. Then I prickled my finger with needle. Three drops of blood was placed on glass slide. One drop of antiserum placed on blood drops. Then I mixed it with the tooth pick. Coagulation occurred on the A and B. No change occurred on D. My blood group was $\mathrm{AB}$.

\section{Project}

A questionnaire was prepared about feet size.

\section{Statistical Analysis}

Statistical analysis was performed by MS Excel. Mean + SD were calculated.

\section{Results and Discussion}

$\mathrm{A}+$ subject has maximum feet while $\mathrm{AB}$ - and $\mathrm{A}$ individuals have minimum or small size feet. The total ratio of $A$ positive female 7.8 and male has 1.2.The total ratio of $A$ negative is 0 and 0 .The total ratio of $B$ positive female is 1.3 and male 6.8.The total ratio of $\mathrm{B}$ - is 0.7 and male 0.6.The total ratio of $\mathrm{AB}+$ female has 0.6 and male 


\section{Medical Journal of Clinical Trials \& Case Studies}

ratio is 1.1. AB-has ratio male and female is 0. The ratio of $\mathrm{O}+$ in female has 1.2 and male has 6.9.The total ratio of $\mathrm{O}-$ in female has 0.7 and male has 0.8 .

\begin{tabular}{|c|c|c|}
\hline & Female & Male \\
\hline $\mathrm{A}+$ & 7.8 & 1.2 \\
\hline $\mathrm{A}^{-}$ & 0 & 0 \\
\hline $\mathrm{B}^{+}$ & 1.3 & 6.8 \\
\hline $\mathrm{B}-$ & $\mathbf{0 . 7}$ & 0.6 \\
\hline $\mathrm{AB}^{+}$ & 0.6 & 1.1 \\
\hline $\mathrm{AB}^{-}$ & 0 & 0 \\
\hline $\mathrm{O}^{+}$ & 1.2 & 6.9 \\
\hline $\mathrm{O}^{-}$ & 0.7 & 0.8 \\
\hline
\end{tabular}

Table 1: Questionnaire based studies have been given important outcomes in current researches [3-10]. No studies about this project were present.

\section{Conclusion}

It was concluded from present study that gender is of no matter in studying about feet size. Some females have large feet size and some male have large feet size.

\section{References}

1. Qadir MI, Malik SA (2010) Comparison of alterations in red blood cell count and alterations in hemoglobin concentration in patients suffering from rectal carcinoma undergoing 5-fluorouracil and folic acid therapy. Pharmacologyonline Nl 3: 240-243.
2. Qadir MI, Noor A (2018) Anemias Rare \& Uncommon Diseases. Cambridge Scholars Publishing. Newcastle, England.

3. Qadir MI, Javid A (2018) Awareness about Crohn's Disease in biotechnology students. Glo Adv Res J Med Medical Sci 7(3): 062-064.

4. Qadir MI, Saleem A (2018) Awareness about ischemic heart disease in university biotechnology students. GloAdv Res J Med Medical Sci 7(3): 059-061.

5. Qadir MI, Ishfaq S (2018) Awareness about hypertension in biology students. Int J Mod Pharma Res 7(2): 08-10.

6. Qadir MI, Mehwish (2018) Awareness about psoriasis disease. Int J Mod Pharma Res 7(2): 17-18.

7. Qadir MI, Shahzad R (2018) Awareness about obesity in postgraduate students of biotechnology. Int J Mod Pharma Res 7(2): 14-16.

8. Qadir MI, Rizvi M (2018) Awareness about thalassemia in post graduate students. MOJ Lymphology Phlebology 2(1): 14-16.

9. Qadir MI, Ghalia BA (2018) Awareness survey about colorectal cancer in students of M. Phil Biotechnology at Bahauddin Zakariya University, Multan, Pakistan. Nov Appro in Can Study 1(3): NACS.000514.

10. Qadir MI, Saba G (2018) Awareness about intestinal cancer in university student. Nov Appro in Can Study 1(3): NACS.000515. 